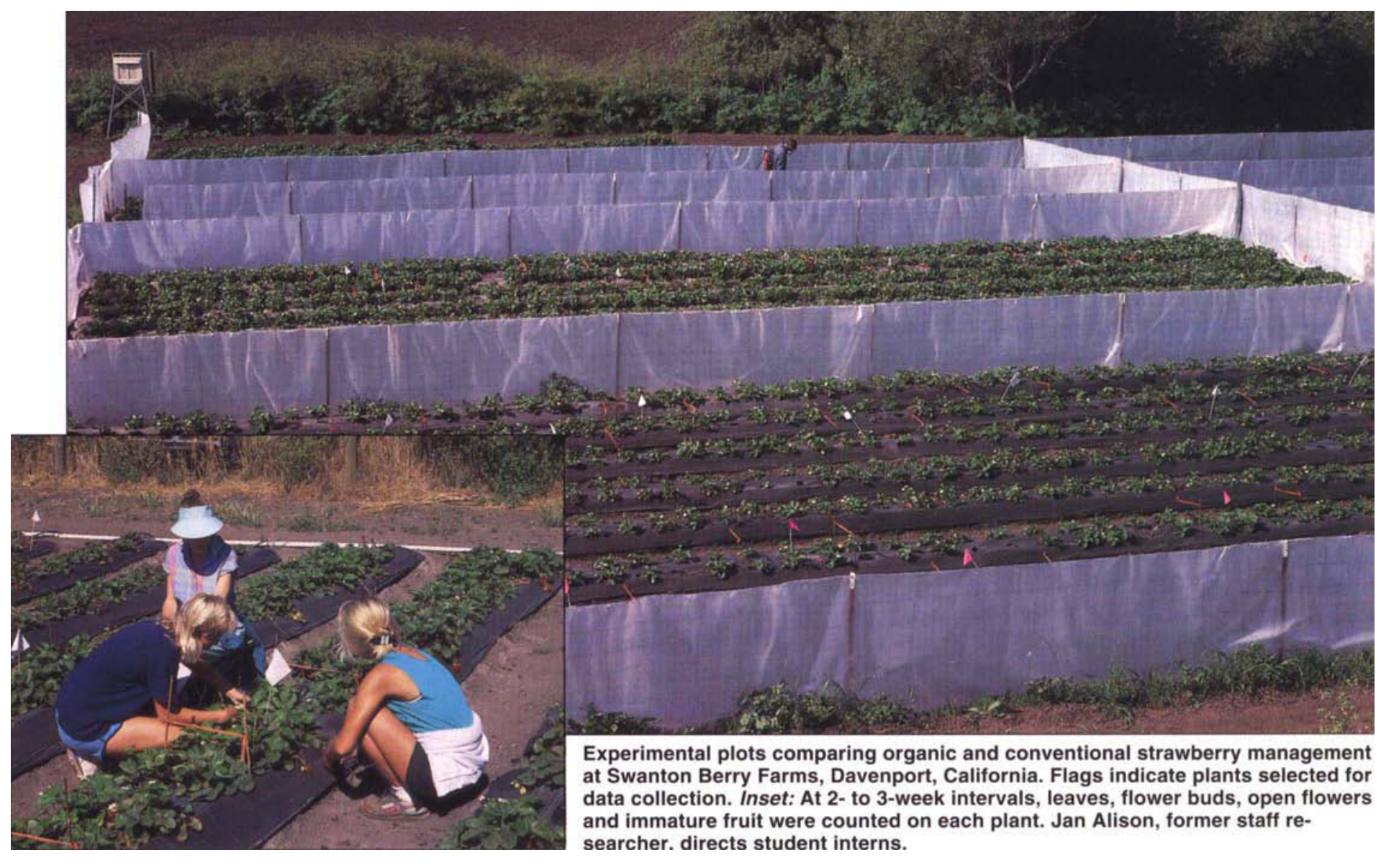

\title{
Conversion to organic strawberry management changes ecological processes
}

Stephen R. Gliessman $\square \quad$ Matthew R. Werner $\square \quad$ Sean L. Swezey $\square \quad$ Ed Caswell Jim Cochran $\square$ Francisco Rosado-May
Growers have several incentives for converting conventional, high-input strawberry production systems to organic systems, including price premiums as high as $50 \%$ in response to consumer demand for organic products, lower production costs and increasing regulation of farm inputs and off-farm impacts. Perhaps most compelling is the classification of the soil fumigant methyl bromide as an ozone depletor and its expected ban. Methyl bromide is used routinely in conventional strawberry systems to suppress soilborne diseases and to kill weed seeds.

California's annual strawberry crop is currently valued at more than $\$ 300$ million, and accounts for about $75 \%$ of fresh strawberries consumed in the United States. Most of the state's crop is grown on the coast, with more than half of the 19,250 acres in Central Coast counties. Although strawberry profits can exceed $\$ 6,000$ per acre, input costs are quite high. Conventional practices require preplant fumigation, plastic mulch, drip irrigation, appropriate preplant chilling, fertilization with slow-release nutrients, foliar applications of synthetic pesticides and concentrated semipermanent hand labor throughout the growing season.

We conducted a 3-year study on strawberry production systems with the following goals: to use a systems approach to identify factors that may limit yields during the conversion to organic management; to evaluate the effectiveness of alternative input and management practices; and to detail 
changes in soil characteristics; pest, disease, and beneficial populations; crop response; and economic costs and benefits. In 1990 we reported the first year results (California Agriculture JulyAugust 1990). Here we report conclusions from the completed study.

\section{Establishing the plots}

In fall 1987 we began work at Swanton Berry Farms - a small-scale strawberry operation located 5 miles north of Santa Cruz - establishing annual strawberry production on twelve 48.75-foot-by-16.25-foot plots of four double-row beds, separated by 4 -foothigh plastic fences on a $1 / 2$-acre field. The plots were arranged in a randomized complete block design, with six randomly selected pairs of the following two treatments blocked along a gentle slope: (1) conventional production guidelines recommended by UC Cooperative Extension, and (2) management without synthetically derived inputs, in accordance with the California Health and Safety Code Section 2659.11-.17 and the California Certified Organic Farmers guidelines and enforcement provisions. The grower was experienced in both conventional and organic strawberry production, but also received advice from a farm advisor. The soil was a Pinto loam from old alluvial deposits on a marine terrace, with a slope of 1 to $2 \%$. The farm had a long history of conventionally grown Brussels sprouts.

Both production systems were winter covercropped with a bell bean and barley mixture, which was disked and incorporated in May 1987, 6 months before plantout. Chandler strawberries were planted on a winter-planting schedule in both production systems. During the first year of the study, plantout was during the first week of November, harvest began in late March 1988, and final harvest and plant removal were completed in September 1988. The second-year crop was planted in mid-October 1988, harvest began in early April 1989, and final harvest was completed during the second week of September 1989. Based on research results and farmer experience and recommendations, plants were pruned and left in the ground for a second year of production for the 1989-1990 season. Harvest in the third year began in April 1990 and continued until the plants were incorporated in August 1990, when we terminated the experiment.

Conventional production system. In the conventional production system (CPS), the soil was leveled and chiseled. Following sprinkler irrigation to moisten the cultivated layer, soil was rototilled to a depth of 8 to 10 inches before fumigation. In the first two years of the study, the system was bed-fumigated with a 2:1 mix of methyl bromide and chloropicrin. The plants were dipped in benomyl (Benlate-WP) before planting. At plantout, 0.23 ounce per plant of an encapsulated, timed-release fertilizer (Eskote 26N-8P-8K in years 1 and 3; Osmocote $18 \mathrm{~N}-7 \mathrm{P}-13 \mathrm{~K}$ in year 2 ) was placed in the planting hole 0.5 inch below root depth. In the third growing season, fertilizer was added in the middle of the bed under the drip line. The plants were sprinkler irrigated as needed through November, with a standard strawberry drip tape installed immediately before mulching with clear plastic in early December.

Pesticides used during the study included Benlate as a preplant dip; Captan for Botrytis leaf spot control in the wet months of January and February; malathion for lygus bug control in May of year 1; Dibrom for lygus bug control in May of year 2; and Vendex, Kelthane, and Avermectin for twospotted spider mite (Tetranychus urticae) control during April and May of years 1 and 2 . Timing of pesticide applications was based on local farm advisor recommendations.

Organic production system. In the organic production system (OPS), soil was prepared in an identical manner but without fumigation. A commercially available compost $(1.5 \mathrm{~N}-2 \mathrm{P}-2 \mathrm{~K}-$ $1.5 \mathrm{Ca}$ ) made from dairy waste, alfalfa, cotton gin trash and apple residue was incorporated at 7.5 tons / acre (year 1), 15.0 tons / acre (year 2) and 7.5 tons / acre (year 3). This material has an organic matter content of $36 \%$, with a C:N ratio of 18. At plantout in year 1 , a small amount of $14 \% \mathrm{~N}$ bloodmeal $(0.14 \mathrm{oz})$ was placed between each plant and the drip tape at a 3-inch depth. The same amount of bonemeal was applied in years 1 and 2. Beds were covered with black plastic mulch to control weeds and conserve water, and the plots were hand weeded as necessary. Based on the lower soil temperatures observed in the organic plots in year 1, OPS beds in year 2 were covered with a floating row cover from plantout until initial fruitset in late February to raise soil temperatures. In year 3 , the row covers could not be used because flowering began very early in the 2-year-old plants. In March 1989 (year 2) there were two releases of insectary-reared Phytoseiulus persimilis, a predaceous mite, into the organic plots at the rate of 16,000 per acre. An additional 20,000 per acre were released in November 1989 (year 3) on recently pruned plants.

\section{Evaluation procedures}

Soil characteristics for both CPS and OPS were evaluated based on four separate samples (collected before and after fall planting, before fruiting in the spring and during peak harvest) of 20 pooled, 3/4-inch-diameter soil cores per replicate to a depth of 6 inches. Composite samples were air dried, ground and submitted to a soiltesting laboratory (Harris Labs, Lincoln, Nebraska) for analysis (table 1). Soil temperatures were monitored biweekly at approximately 2 -inch and 5-inch depths at 10 locations per plot within the plant row, using a Yellow Springs telethermometer.

Strawberry plant development and fruit yield were monitored on the basis of permanent "pick-plots" of 20 (year 1) and 16 (years 2 and 3 ) plants selected with a random numbers table from each 792-square-foot plot. At 2to 3-week intervals, we counted the leaves, flower buds, open flowers and immature fruit on each plant. Ripe fruits from these plants were harvested and graded (market or reject) twice a week, and weight recorded as an estimate of yield. Rejected fruits were not included in market yield. A destructive, whole-plant sample of 5 randomly selected plants was collected approximately every 6 weeks. 
The leaf area of the sample plants was determined using a LiCor LI-3000 area meter. Plant material was separated into two categories - vegetative (aboveground crowns, leaves and runners) and reproductive (flower stalks, flowers and fruit) - dried at $140^{\circ} \mathrm{F}$ and weighed. Nutrient analysis on plant parts was performed, but not reported here.

Aboveground arthropods (except mites) were monitored using a 10plant (year 1) or 20-plant (year 2) DVAC suction sample in the two center rows of each four-row plot, and in a weedy border of mostly grasses, wild mustard and wild radish at the edge of the experimental field. Twospotted spider mites and predaceous mites were monitored in a biweekly (year 1) or weekly (years 2 and 3 ) sample of 10 (year 1) or 20 (years 2 and 3 ) randomly selected midtier leaflets from the two center rows of each plot. Eggs and active stages of all mites encountered were counted under a dissecting mi- croscope. Lygus bugs (Lygus hesperus) were monitored weekly with a 20 plant beat sample using a standard insect net. Western flower thrips (Frankliniella occidentalis) were monitored biweekly (year 1) or weekly (years 2 and 3) by placing 10 recently opened flowers per replicate for several minutes into a small, tight-lidded plastic container along with a cotton plug saturated with methyl isobutyl ketone.

All plots and borders were separated by a 4-foot-high plastic fence to minimize pesticide drift and migration of organisms between plots and from plot borders. However, small plot size and potential edge effects limited our ability to control movement of the most mobile arthropods.

The presence of genera of the most common strawberry plant pathogens was evaluated at 6-week intervals by plating on selective media 1/2-inch segments of 10 pieces of healthy mature roots from each of five plants per replicate. The presence or absence of

\begin{tabular}{|c|c|c|c|c|c|c|}
\hline & \multicolumn{3}{|c|}{ Conventional } & \multicolumn{3}{|c|}{ Organic } \\
\hline & Year 1 & Year 2 & Year 3 & Year 1 & Year 2 & Year 3 \\
\hline$\%$ organic matter & 3.7 & 3.2 & 2.8 & 3.6 & 3.3 & $2.9^{*}$ \\
\hline$N($ total \%) & 0.23 & 0.28 & 0.21 & 0.24 & $0.32^{*}$ & $0.23^{\circ}$ \\
\hline $\mathrm{P}(\mathrm{ppm})$ & 80.0 & 71.0 & 66.0 & 79.0 & $98.0^{\circ}$ & $90.0^{*}$ \\
\hline $\mathrm{K}(\mathrm{ppm})$ & 412.0 & 310.0 & 297.0 & $463.0^{\circ}$ & $776.0^{\circ}$ & $535.0^{\circ}$ \\
\hline $\mathrm{Mg}(\mathrm{ppm})$ & 203.0 & 193.0 & 179.0 & 217.0 & $278.0^{\circ}$ & $218.0^{\circ}$ \\
\hline $\mathrm{Ca}(\mathrm{ppm})$ & $3,318.0$ & $2,842.0$ & $2,886.0$ & $3,115.0$ & $3,168.0^{\circ}$ & $3,024.0^{\circ}$ \\
\hline $\mathrm{Na}$ (ppm) & 78.0 & 73.0 & 69.0 & 77.0 & $119.0^{\circ}$ & 76.0 \\
\hline CEC & 19.7 & 16.9 & 17.0 & 18.9 & 20.7 & $18.6^{\circ}$ \\
\hline $\begin{array}{l}\text { Soluble salts } \\
(\mathrm{mmhos} / \mathrm{cm})\end{array}$ & 0.20 & 0.23 & 0.40 & 0.21 & $0.64^{*}$ & 0.44 \\
\hline $\mathrm{S}(\mathrm{ppm})$ & nd $t$ & nd & 24 & nd & nd & 27 \\
\hline $\mathrm{Zn}(\mathrm{ppm})$ & nd & nd & 4.2 & nd & nd & 4.1 \\
\hline Mn (ppm) & nd & nd & $11.5^{*}$ & nd & nd & 8.2 \\
\hline $\mathrm{Cu}(\mathrm{ppm})$ & nd & nd & 1.6 & nd & nd & 1.4 \\
\hline $\mathrm{Fe}(\mathrm{ppm})$ & nd & nd & 21.7 & nd & nd & 20.2 \\
\hline B (ppm) & nd & nd & 0.6 & nd & nd & $1.2^{*}$ \\
\hline $\mathrm{NO}_{3}(\mathrm{ppm})$ & nd & nd & 34 & nd & nd & 33 \\
\hline $\mathrm{pH}$ & nd & 7.75 & 7.53 & nd & 7.77 & 7.73 \\
\hline
\end{tabular}

- Statistically significant treatment differences for that sample date (alpha $\leq 0.05$ ).

$\dagger \mathrm{nd}=$ no samples taken .

TABLE 2. Strawberry plant development and yield in the conventional and organic treatments

\begin{tabular}{lccc}
\hline \hline & Year & Conventional & Organic \\
\hline Maximum dry vegetative & 1 & $2.2(0.9)^{*}$ & $3.0(0.6)$ \\
wt/plant (oz.), above ground & 2 & $2.9(0.8)$ & $1.5(0.3)$ \\
& 3 & $2.0(0.5)$ & $1.5(0.3)$ \\
Maximum number & 1 & $55.6(7.9)$ & $53.8(4.4)$ \\
of leaves/plant & 2 & $61.5(13.3)$ & $34.8(2.1)$ \\
& 3 & $92.7(17.9)$ & $60.3(9.2)$ \\
Maximum total leaf & 1 & $674(221)$ & $837(136)$ \\
area/plant (sq. inches) & 2 & $774(198)$ & $405(55)$ \\
& 3 & $690(134)$ & $462(80)$ \\
Marketable fruit yield, & 1 & $2.10(0.17)$ & $1.28(0.13)$ \\
Ib/plant & 2 & $2.08(0.23)$ & $1.44(0.15)$ \\
& 3 & $2.06(0.33)$ & $1.48(0.27)$ \\
"standard error in () & & &
\end{tabular}

pathogens was scored on a percentage basis. Nematode density was evaluated at the beginning of each season on the basis of five pooled soil samples per replicate, centrifuged in a 100-gram subsample in a sucrose solution, then counted and identified under a dissecting microscope. In year 3 , roots were examined for endoparasitic nematodes. To assess colonization by vesicular-arbuscular mycorrhizae (VAM), we randomly selected $1 / 2$-inch pieces of healthy mature roots from each root sample, cleared of color, stained with trypan blue-lactophenol solution for colonization and determined the colonization percentage.

We compared labor and materials cost in each of the three years based on a combination of grower estimates from postseason interviews and UC Cooperative Extension standard costof-production data for winter-planted strawberries on the Central Coast. Adjustments in costs were made for management changes in years 2 and 3 , and we added a $5 \%$ annual inflationary increase in operating costs over baseline for both production systems. Yield and income were calculated by combining the observed yields on a plot basis with average market price for the season reported by the grower.

Comparisons between variables were performed using the two-way ANOVA technique for a randomized, complete block design, with appropriate transformations of non-normal distributed data.

Monitoring revealed a number of similarities and significant differences between the production systems, as well as changes in both systems over the 3 years.

\section{Soil characteristics}

Total organic matter content apparently decreased in both production systems over the 3 years (table 1 ). The shift from Brussels sprouts, which commonly have a winter covercrop period, to constant strawberry coverage obviously reduced organic returns to the soil. Organic matter content was significantly greater in the OPS in year 3 , possibly reflecting the use of organic fertilizers.

There were significantly higher levels of $\mathrm{K}$ in the OPS in all three years, 

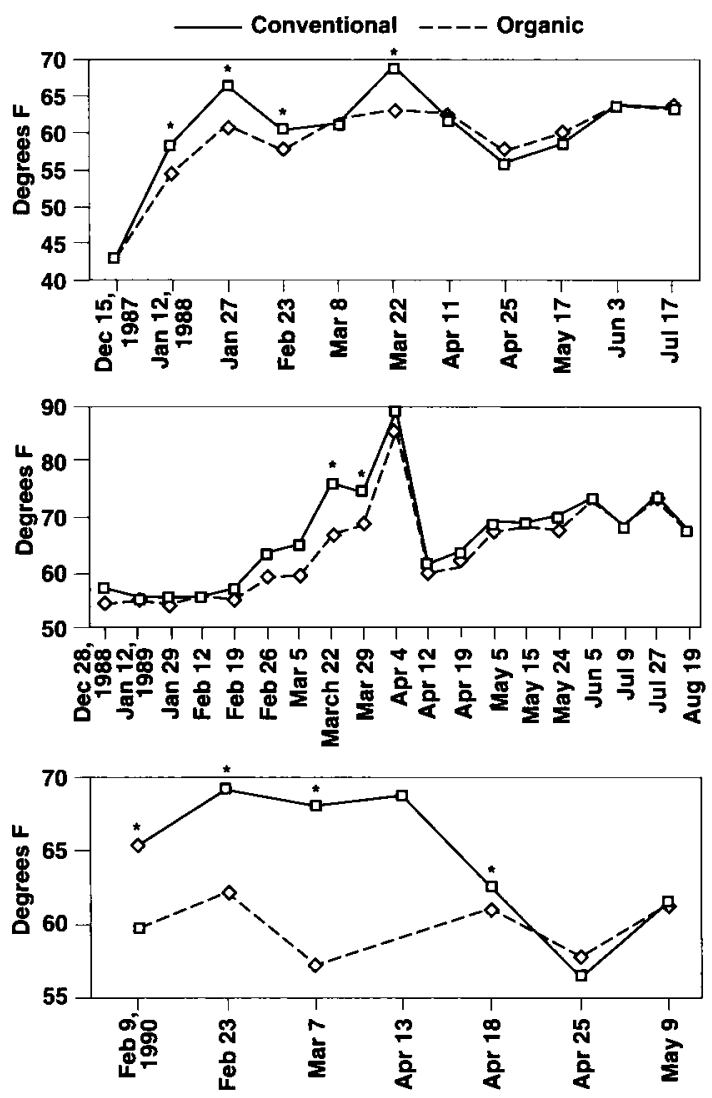

Fig. 1. Soil temperatures 2.5 -inch depth over 3 years. Asterisk denotes sample dates when conventional was significantly greater than organic.

and greater amounts of $\mathrm{N}, \mathrm{P}, \mathrm{Mg}$ and $\mathrm{Ca}$ in years 2 and 3 (table 1 ). Soluble salt and Na levels were significantly greater in the OPS in year 2, and cation exchange capacity and $B$ levels were greater in year 3 . Manganese was the only nutrient that was significantly higher in the CPS by the end of year 3 .

In year 1 , soil temperatures were significantly higher in the CPS during January, February and March. This difference was narrowed somewhat in year 2 by using row covers over the organic plants in early spring. Row covers were not used in year 3 , and significant differences in soil temperature at both depths were seen again (fig. 1).

\section{Plant development and fruit yield}

Plant development, as measured by number of leaves, total leaf surface area and vegetative biomass, was always greater in the CPS during the early part of the production season. In year 1, final plant development in the OPS was greater than in the CPS (table 2 ). In years 2 and 3 , vegetative growth in the OPS was lower than year 1.
Total marketable fruit yield from the CPS (tables 2 and 4) was slightly below average for the region. The farm is located very close to the coast, several miles to the north of the main production areas of the Monterey Bay region, where cooler conditions may have limited plant development. Yields from the OPS, relative to those from the CPS, were $39 \%$ lower year $1,30 \%$ year 2 , and $28 \%$ year 3 . Yields in both production systems typically peaked in late May/June, with a second, smaller peak late in the summer (data not shown).

\section{Arthropod, disease populations}

In year 1 (fig. 2), three acaricide applications effectively kept populations of twospotted spider mite
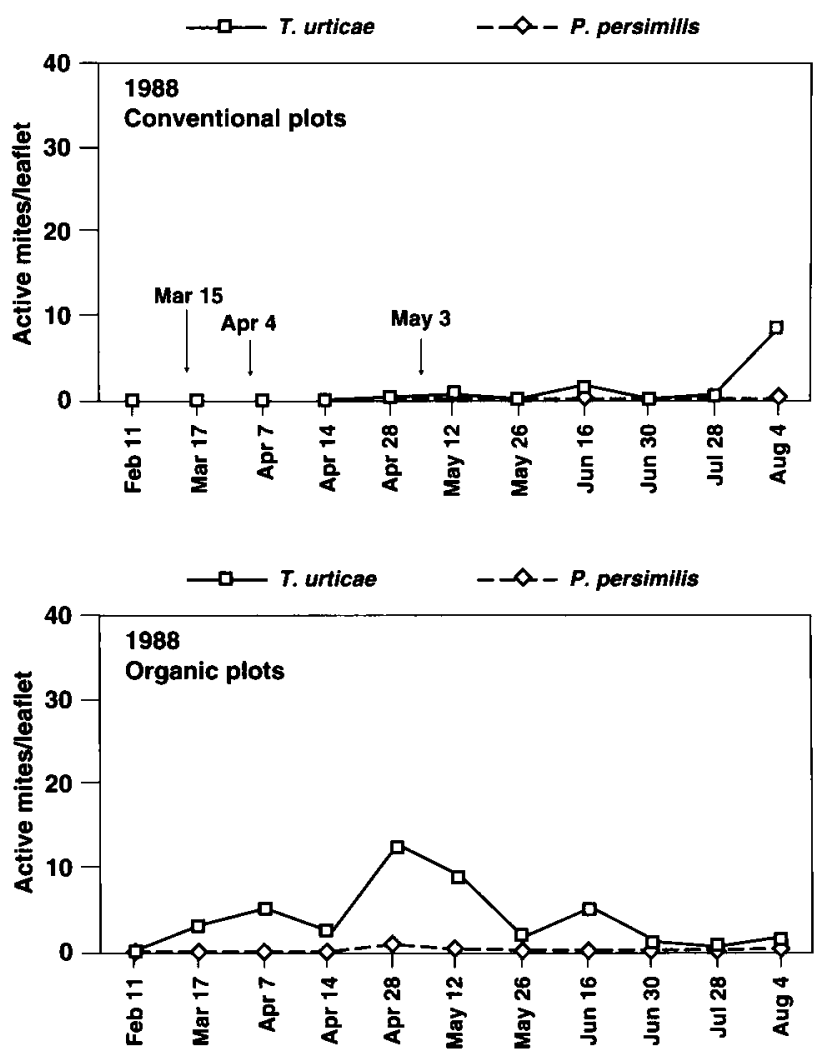

Fig. 2. Seasonal dynamics of pest TSSM (Tetranychus urticae) and beneficial (Phytoseiulus persimilis) mite populations, 1988. Arrows indicate dates of acaricide applications in conventional treatment plots.
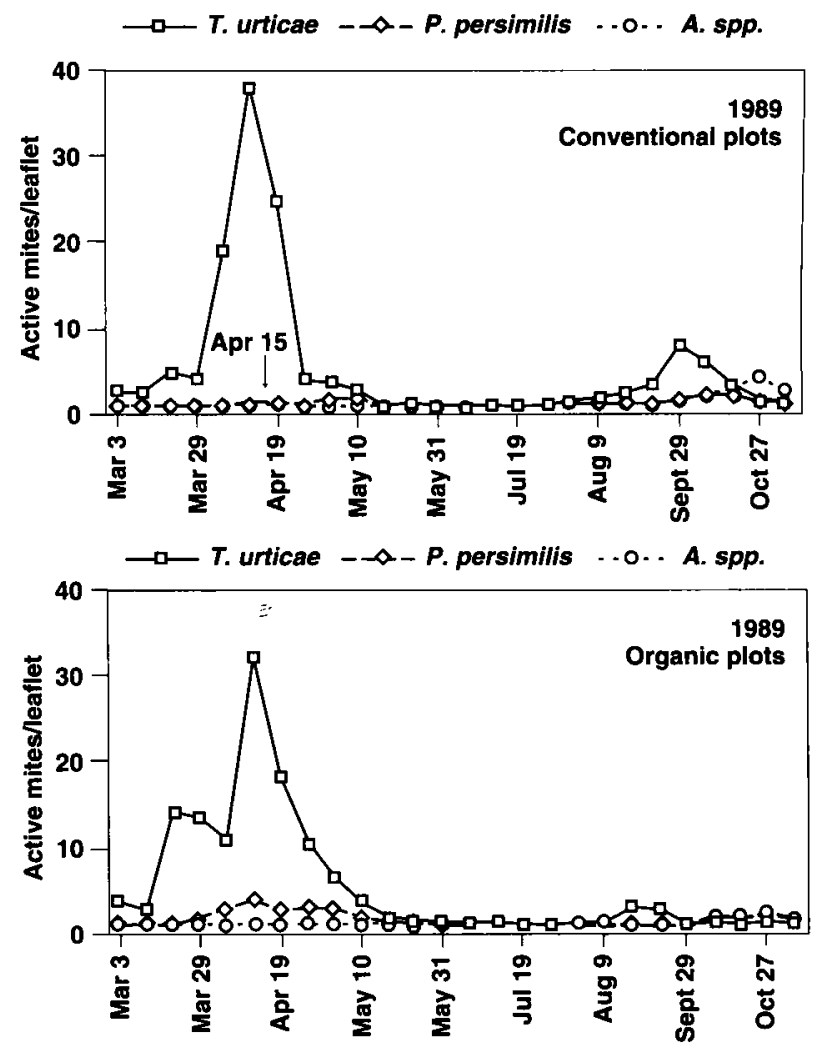

Fig. 3. Seasonal dynamics of pest TSSM (Tetranychus urticae) and beneficial (Phytoseiulus persimilis and Amblyseius spp.) mite populations, 1989. Arrows indicate dates of acaricide applications in conventional treatment plots. 

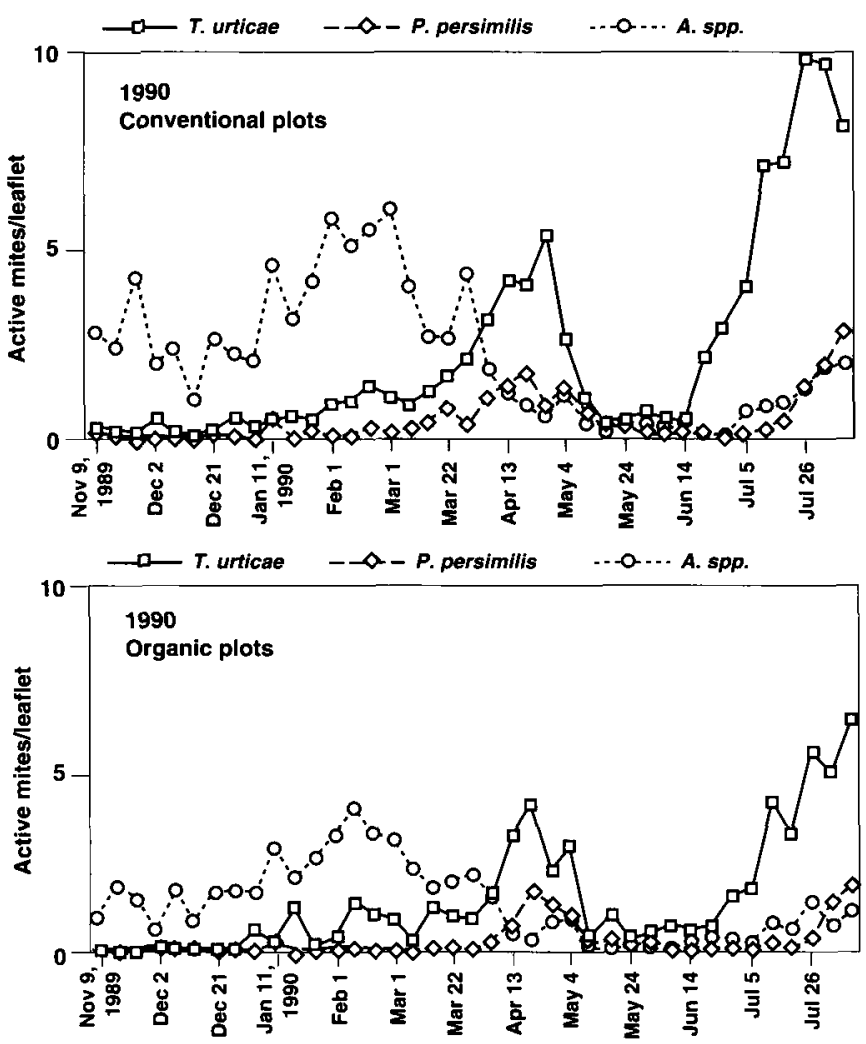

Fig. 4. Seasonal dynamics of pest TSSM (Tetranychus urticae) and beneficial (Phytoseiulus persimilis and Amblyseius spp.) mite populations, winter 1989 through 1990 harvest.

(TSSM) in the CPS below critical economic threshold levels (above 10 mites per leaflet for fresh market production). Although TSSM reached higher levels in the OPS, biweekly means exceeded the threshold on only one sample date. In year 2 (fig. 3), no significant differences were seen in TSSM populations in the two production systems, although TSSM peaks in year 2 (approximately 30 per leaflet) were significantly higher than in year 1 . During year 3, TSSM populations were relatively low in both production systems. The beneficial mite $P$. persimilis was not introduced during year 1 . In the spring of year 2, P. persimilis was introduced to the OPS and induced a TSSM population reduction in April, similar to the reduction in the CPS in April after an acaricide application (fig. 3 ).

In the absence of acaricide applications after midseason, $P$. persimilis tended to recover in CPS. P. persimilis populations introduced in the OPS in November 1989 successfully overwintered and dispersed into TSSM colo- nies during year 3 (fig. 4). A complex of native phytoseiid species including Amblyseius californicus, A. limonicus and Typhlodromus johnsoni (J. McMurtry, UC Riverside, personal communication) was first detected in 1989. Relatively high overwintering populations of these species were established in both systems during year 3 , but declined with increasing density of $P$. persimilis or the use of acaricides.

The lygus bug was not prevalent in either production system during year 1 , although adults and immatures were detected from noncrop vegetation surrounding the field. Lygus populations increased in year 2 and surpassed economic threshold levels (estimated at 0.25 to 0.5 bug per 20 beats) in June 1989. Insecticides were applied in the CPS, and populations persisted at economic levels in the OPS for 6 weeks after the peak emergence of nymphs in June. In year 3, lygus adults were first detected in late April, and economically damaging densities were observed in late May. Insecticide sprays achieved economic control in the CPS plots; populations also dropped in OPS plots after this date.

In year 1, populations of western flower thrips (Frankliniella occidentalis) were significantly higher in the OPS on two dates following a May malathion application in the CPS (fig. 5). Significant differences were again seen in year 3 for 4 weeks following an insecticide treatment for lygus. Populations did not reach economic density (estimated at 10 per flower) in either system at any time during the study. In all 3 years the thrips predator Orius tristicolor was often observed in the thrips extractions, indicating its preference for thrips habitat in flowers.

Populations of other beneficial arthropods were often more abundant in the OPS (table 3), including the bigeyed bug (Geocoris punctipes), spiders, minute pirate bugs and parasitic $\mathrm{Hy}-$ menoptera. Similar patterns for beneficials were also seen in the previous 2 seasons.

Root fungi. In general, levels of pathogenic root fungi were low in both treatments except for the genus Fusarium (not known as pathogenic to strawberries), and Cylindrocarpon sp., which became more abundant in the OPS in years 2 and 3. (Rosado-May et al., 1994, Applied Soil Ecology 1:261-267) Percent occurrence of Pythium spp. and Rhizoctonia spp. was always greater in organic plots, although numbers were generally low and no disease symptoms were observed. Trichoderma, a beneficial organism, became slightly more abundant in years 2 and 3 in the CPS plots. Verticillium were very low in both treatments throughout the experiment.

We observed root samples for colonization by vesicular-arbuscular mycorrhizal (VAM) fungi, a symbiont that can improve water and nutrient uptake by strawberry plants. In year 1 , VAM colonization of strawberry plants began at very low levels and increased throughout the season (fig. 6), with higher levels observed in the OPS. In year 2 treatment differences increased, with significantly higher levels in the OPS on all sample dates. In year 3, no treatment differences were detected. During all 3 years, colonization levels increased during the harvest period. VAM species were not identified.

Soil nematodes. In years 1 and 2, four genera of plant parasitic nematodes were recorded (Meloidogyne, Tylenchorhyncus, Helicotylenchus and Pratylenchus), along with free-living nematodes. (Rosado-May et al., 1994, Applied Soil Ecology 1:261-267) Populations of both parasitic and free-living nematodes (saprophytes and predators on plant-parasitic nematodes) were much greater in the OPS in years 1 and 2 . In year 3 , plant-parasitic nematodes showed a very significant 

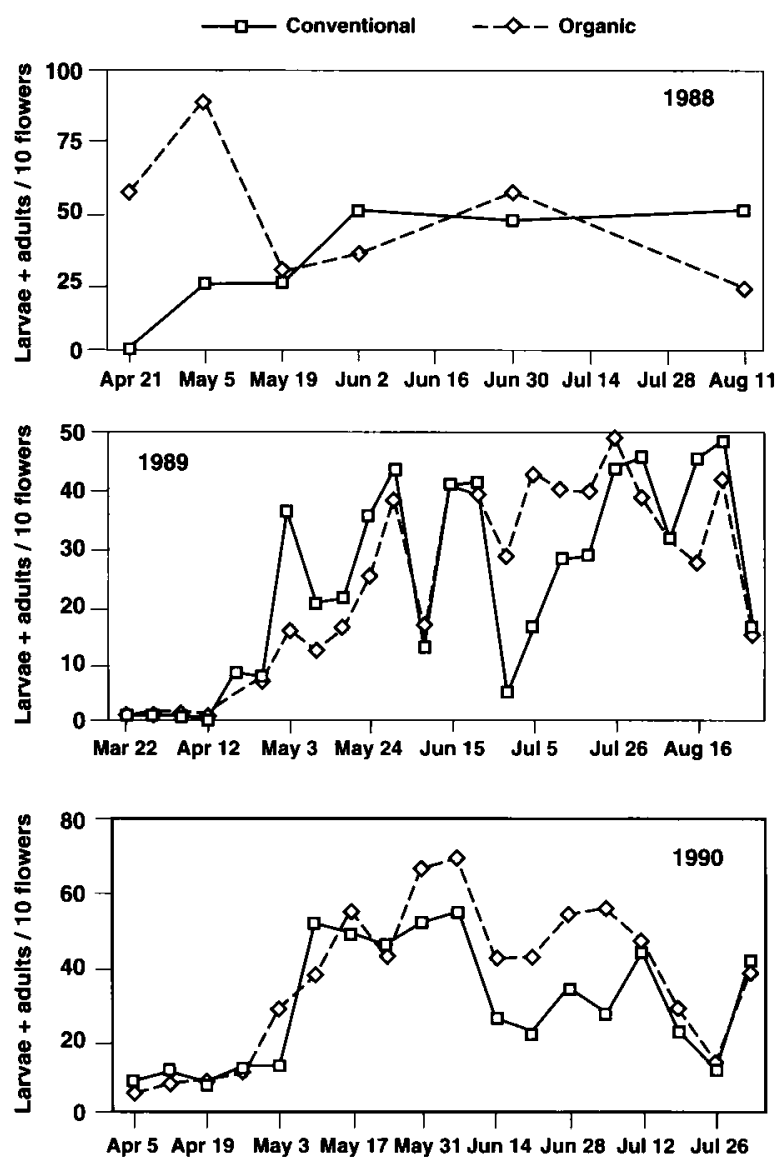

Fig. 5. Seasonal dynamics of the western flower thrips (Frankliniella occidentalis).
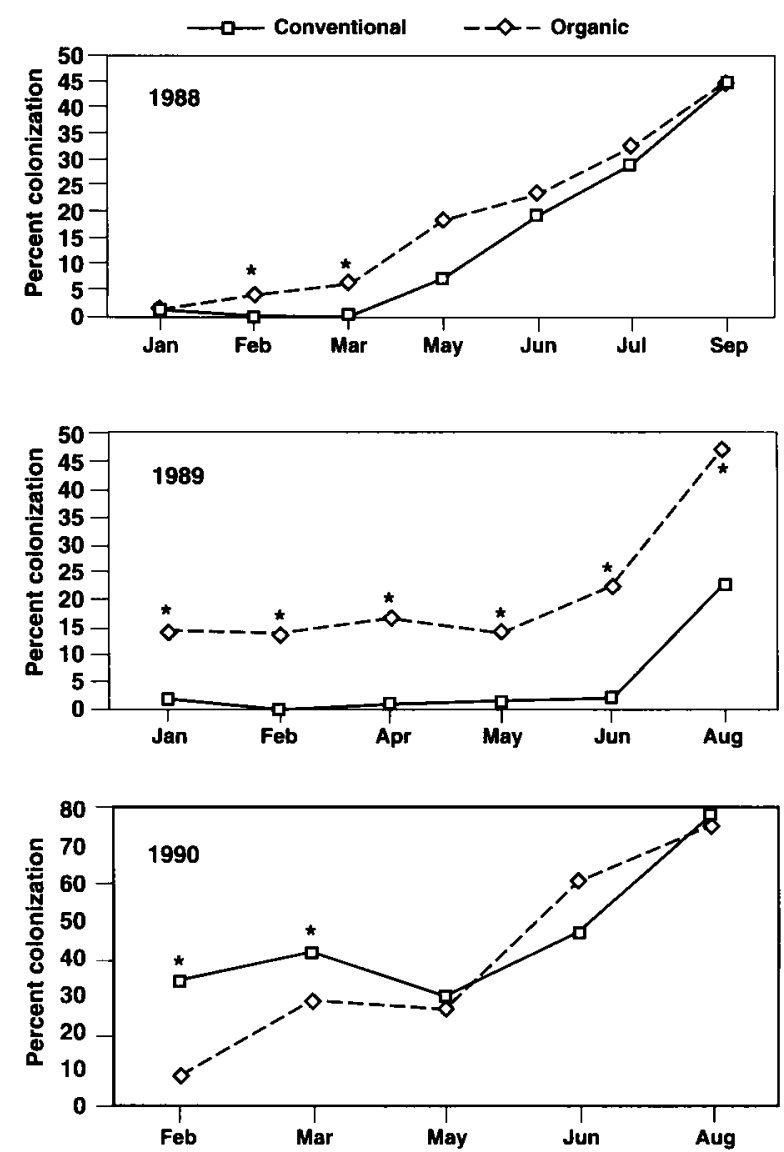

Fig. 6. Percent vesicular-arbuscular mycorrhizal colonization of strawberry roots over 3 years. Asterisks indicate statistically significant differences for that sample (alpha $\leq \mathbf{0 . 0 5}$ ). drop in both systems. Both bacterialfeeding nematodes (Rhabditis, Acrobeloides, others) and fungal feeders (Tylenchus spp.) were consistently more abundant in the OPS. Very little evidence of endoparasitic nematodes in roots was found in either system. Relative to the number of free-living nematodes (bacterial and fungal feeders), the total number of plant-parasitic nematodes was low in both systems.

\section{Production costs and income}

In the first 2 years, nonrenewable input costs associated with pesticides, fertilizers and fuel were higher in the CPS, but the OPS required more hours of 25-horsepower tractor work for mechanical weeding (table 4). Additional weeding and the longer picking time per unit of yield led to higher labor costs in the OPS. The higher price for organic strawberries during this study permitted a positive profit margin, despite lower production levels. Stricter

\begin{tabular}{|c|c|c|c|c|c|c|}
\hline \multirow{2}{*}{$\frac{\text { Week }}{\text { (Postpruning) }}$} & \multicolumn{2}{|c|}{ Geocoris spp. } & \multicolumn{2}{|c|}{$\begin{array}{l}\text { Other key pest } \\
\text { predators* }\end{array}$} & \multicolumn{2}{|c|}{ Spiders } \\
\hline & Conventional & Organic & Conventional & Organic & Conventional & Organic \\
\hline 21 & 0 & 0 & 1.3 & 1.6 & 5.5 & $14.3 t$ \\
\hline 22 & 0 & 0.2 & 1.6 & 1.0 & 9.2 & $17.5 t$ \\
\hline 23 & 0.3 & 0 & 1.3 & 1.0 & 9.5 & 11.0 \\
\hline 24 & 0.2 & 0.2 & 1.2 & 0.2 & 11.2 & 19.0 \\
\hline 25 & 0.7 & 1.2 & 1.8 & 0.5 & 15.7 & 19.2 \\
\hline 26 & 0.5 & $4.7 \dagger$ & 5.5 & 4.3 & 22.2 & 23.5 \\
\hline 27 & 0.3 & $2.0+$ & 1.5 & 2.2 & 28.3 & 26.8 \\
\hline 28 & 0.3 & 0.7 & 1.5 & 1.2 & 20.0 & 12.8 \\
\hline 29 & 0.2 & 0.2 & 4.2 & 3.0 & 9.8 & 13.2 \\
\hline 30 & 1.2 & 2.2 & 2.5 & 1.8 & 15.0 & 21.0 \\
\hline 31 & 2.5 & 2.0 & 0.2 & $2.5 \dagger$ & 15.0 & 21.7 \\
\hline 32 & 1.7 & $3.7 \dagger$ & 1.5 & $3.3 t$ & 5.8 & $21.5 t$ \\
\hline 33 & 0.8 & $2.5 t$ & 1.5 & $3.0 t$ & 6.5 & 16.3 \\
\hline 34 & 1.0 & 0.7 & 2.3 & $3.8 t$ & 7.8 & $14.2 \dagger$ \\
\hline 35 & 0.5 & $2.7 \dagger$ & 4.5 & 4.0 & 13.0 & $27.8 \dagger$ \\
\hline 36 & 0.2 & 0.5 & 2.2 & 1.8 & 6.7 & 12.0 \\
\hline 37 & 0.2 & 0.3 & 2.3 & 2.2 & 6.3 & 11.2 \\
\hline 38 & 0.2 & 1.2 & 6.2 & 7.6 & 22.3 & 33.8 \\
\hline
\end{tabular}


market regulations on organic produce, especially on transitional systems, could become a significant barrier to the adoption of organic techniques.

In the third year leaving the plants in the ground saved approximately $\$ 309$ / acre of cultural labor costs in the CPS (on planting labor) and $\$ 1,717 /$ acre in the OPS (on weeding labor). Approximately $\$ 1,500 /$ acre was saved by not fumigating the CPS plots with methyl bromide/chloropicrin. Mulching the beds immediately after pruning eliminated the need to hand weed the OPS plots, which accounted for most of the savings in cultural labor. Leaving the plants for a second year also saved money in field materials and power - $\$ 3,648$ / acre in the CPS and $\$ 3,032 /$ acre in the OPS.

\section{Discussion}

Over the 3 years, we observed a number of trends in the OPS not seen in the CPS, including slower plant growth, lower yields and increased labor requirements. We also observed little economically important pest damage and no nutrient deficiencies in the OPS, an increase in naturally occurring predators with the absence of insecticidal sprays, higher levels of beneficial nematodes and a positive economic return in both systems. However, yields were still less in the organic system.

These trends present a challenge to growers switching to organic growing methods and to researchers. Managing a less input-intensive system, such as an organic strawberry operation, requires more than just eliminating synthetic chemical inputs. The grower must recognize and react to the system's ecological processes, as well as develop effective practices.

Lower soil temperatures in early spring may account for slower plant growth in the OPS and possibly played a role in lower yields. Higher soil temperatures in the CPS plots may lead to greater nutrient uptake and accelerated growth, partially accounting for the more rapid plant development. In year 2, the grower compensated for the temperature differences observed in year 1 by using row covers in the first 2 months of the growing season, but the yield was still $30 \%$ less. Obviously, soil temperature differences are only part of the problem. Research is needed on the more complex management of nutrients in organic systems.

In year 3 the grower left his plants in for a second year. In an organic system, a second-year crop may promote more effective development of beneficial arthropod, fungal or nematode complexes. However, second-year plants have other management problems. Row covers could not be used in the early season because the plants had begun to flower in the winter months, and significant temperature differences were again observed. Compost was more difficult to incorporate. The timing of pruning must be refined,

\begin{tabular}{|c|c|c|c|c|c|c|}
\hline \multicolumn{7}{|c|}{$\begin{array}{l}\text { TABLE 4. Comparative strawberry production system costs and returns ( } \$ \text { per acre). } \\
\text { Figures based on grower interview. }\end{array}$} \\
\hline & \multicolumn{3}{|c|}{ Conventional } & \multicolumn{3}{|c|}{ Certified organic } \\
\hline & Year 1 & Year 2 & Year 3 & Year 1 & Year 2 & Year 3 \\
\hline $\begin{array}{l}\text { Cultural } \\
\text { labor" }\end{array}$ & 8,194 & 8,755 & 8,446 & 9,613 & 10,094 & 8,377 \\
\hline $\begin{array}{l}\text { Materials \& } \\
\text { field power }\end{array}$ & 13,474 & 14,148 & 10,500 & 10,770 & 12,176 & 9,144 \\
\hline $\begin{array}{l}\text { Interest on } \\
\text { working } \\
\text { capital (10\%) }\end{array}$ & 1,534 & 1,534 & 1,534 & 1,397 & 1,397 & 1,397 \\
\hline Total costs & 23,346 & 24,437 & 20,480 & 21,780 & 23,668 & 18,919 \\
\hline $\begin{array}{l}\text { Total } \\
\text { yieldst }\end{array}$ & 3,388 & 3,342 & 3,321 & 2,068 & 2,324 & 2,388 \\
\hline $\begin{array}{l}\text { Total } \\
\text { value }\end{array}$ & 27,103 & 26,741 & 26,568 & 24,820 & 27,890 & 28,658 \\
\hline Return & 3,756 & 2,303 & 6,087 & 3,039 & 4,222 & 9,738 \\
\hline
\end{tabular}


flect these numbers, presumably because the predator complex exerted control.

No evidence of disease outbreaks caused by pathogenic root fungi was seen in either production system. This may have been due in part to the site's long cropping history of nonhost Brussels sprouts. Phytophthora, a major fungal pathogen of strawberries, was not seen. Verticillium and Rhizoctonia were practically nonexistent in the OPS; they were more frequent, although in low numbers, in the CPS. The exception to these relatively low levels of fungi was Cylindrocarpon, normally a saprophyte, which increased dramatically during year 2 , and also began to increase in the CPS during year 3 when the plot was not treated with methyl bromide/chloropicrin.

Cylindrocarpon is thought to be associated with black root rot, but its role has not been determined. Experiments have shown that its presence can also enhance plant growth and phosphorus (P) uptake, especially when present on mycorrhizal plant roots, indicating a synergistic effect between the two fungi. Trichoderma was encountered in the years 2 and 3, mainly in the CPS. Known to be resistant to methyl bromide/chloropicrin, this fungus is a parasite on other fungi, and in higher numbers might suppress other pathogens.

In spite of high soil P levels, VAM colonization levels increased greatly toward season's end in both systems, although methyl bromide suppressed VAM early in the season. We speculate that plant uptake might create a microzone of $P$ depletion around the roots, even when soil levels are high. High $\mathrm{P}$ demand during fruiting, when new root growth is likely to be minimal, coupled with a depletion zone may create conditions where VAM colonization benefits the plant, despite gross soil and compost levels of $P$ that indicate otherwise. Roots of organic plants do not develop as abundantly as in fumigated soils; therefore VAM may serve as a backup nutrientabsorbing system.

The observed dynamics in nematode community structure suggest that the OPS promotes higher population

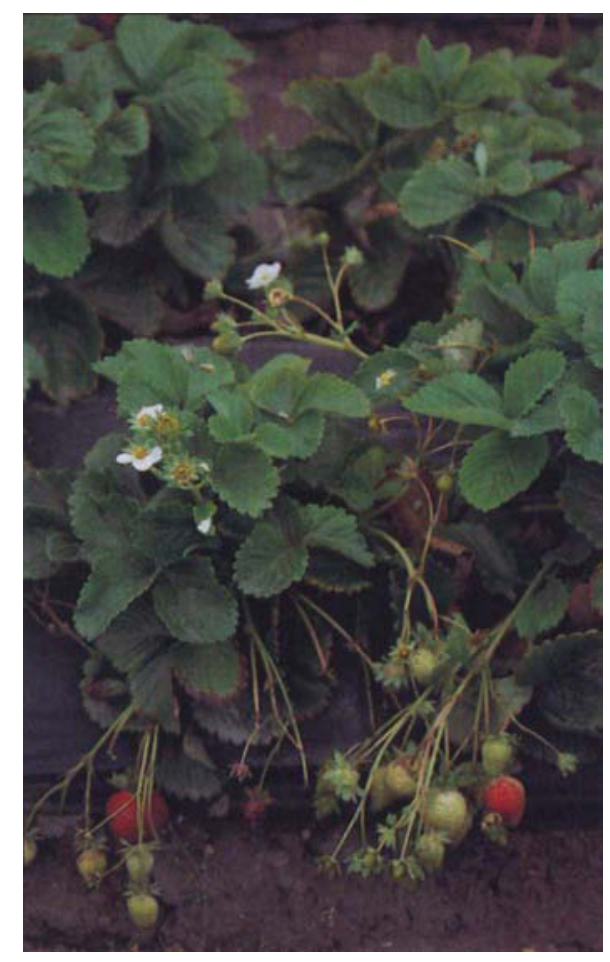

Yields were lower in the organically managed Chandler strawberries.

densities of free-living, non-plantparasitic nematodes, probably as a result of increased soil organic matter and microbial activity. Free-living nematodes include predaceous species that help regulate pest populations and microbial feeders that play a role in nutrient mineralization. Such diversity may play a role in disease suppression.

The relatively high return for the organic crop, especially in year 3 , must be considered in light of several factors. First, this study took place when growing conditions and prices for organic strawberries were extremely favorable. Such conditions can vary widely from year to year. Second, costs and returns reported here do not reflect the cost of a 1- to 2-year fallow period after 2 to 3 years of cropping. During the fallow period - part of a pest control and soil fertility management program - land is covercropped and no returns are realized. (No such fallow period occurred during the study.) The grower estimates rotation costs $\$ 2,000$ to $\$ 2,500$ per fallow acre per year. Planting a different crop may compensate for not planting strawberries. Finally, costs and returns were based on a relatively small-scale operation, which may not translate to larger operations. If all large growers shifted to organic management, the price differential would be greatly reduced. At the same time, organic growing might be more favorable for small farms where out-of-pocket labor costs would be less if family members do more of the work.

\section{Conclusions}

A 3-year comparison of conventional and organic strawberry production systems on the coast north of Santa Cruz, in a field where strawberries had not been grown before, showed yield reductions inherent in the conversion to organic management. Despite these reductions, a grower can profit during transition when the market price for organic strawberries is higher.

Converting a conventional production system that relies heavily on synthetic inputs to a certifiable organic system is not a matter of withdrawing inputs without compensation. We need better knowledge about the mechanisms of yield suppression or enhancement, especially in organic systems where effective management requires considerable ecological knowledge. On-farm grower/researcher/extension collaboration is important to test and modify farming practices. The true test for the conversion process will be in a field with a long history of strawberry cultivation, where the most difficult limiting factors are encountered.

\section{S.R. Gliessman is the Alfred Heller} Professor of Agroecology in Environmental Studies; M.R. Werner is Research Associate, Center for Agroecology and Sustainable Food Systems (CASFS); and S.L. Swezey is Farm Extension Coordinator, CASFS, and Lecturer in Environmental Studies, all at UC Santa Cruz; E. Caswell is Nematologist, Department of Nematology, UC Davis; J. Cochran owns Swanton Berry Farms in Davenport, Calif.; and F. Rosado-May was a graduate student with the CASFS, UC Santa Cruz, and is now with the Universidad de Quintana Roo, Quintana Roo, Mexico. 